\title{
SGK1 activation exacerbates diet-induced obesity, metabolic syndrome and hypertension
}

\author{
Catalina Sierra-Ramos1,*, Silvia Velazquez-Garcia1,*, Arianna Vastola-Mascolo, Guadalberto Hernández , \\ Nourdine Faresse ${ }^{2, \dagger}$ and Diego Alvarez de la Rosa ${ }^{1}$
}

\author{
'Department of Basic Medical Sciences, Institute of Biomedical Technologies and Center for Biomedical Research of the Canary Islands (CIBICAN), \\ Universidad de La Laguna, Tenerife, Spain \\ Institute of Anatomy, University of Zurich, Zurich, Switzerland
}

Correspondence should be addressed to D Alvarez de la Rosa: diego.alvarez@ull.edu.es

*(C Sierra-Ramos and S Velázquez-García contributed equally to this work)

${ }^{\dagger}(\mathrm{N}$ Faresse is now at DIVA Expertise, 1 Place Pierre Potier, Toulouse, France)

\begin{abstract}
The serum- and glucocorticoid-induced kinase 1 (SGK1) is a transcriptional target of steroid hormones including glucocorticoids or aldosterone in addition to other stimuli such as glucose. SGK1 is activated via phosphoinositide 3-kinase, placing it downstream of insulin signaling. SGK1 participates in the upregulation of kidney $\mathrm{Na}^{+}$ reabsorption by aldosterone and has been linked to obesity-related hypertension in humans. We hypothesized that a systemic increase in SGK1 activity may trigger a multiplicity of mechanisms leading to simultaneous development of the main conditions that characterize the metabolic syndrome (MetS), including hypertension. We used a transgenic mouse model made with a bacterial artificial chromosome containing the whole mouse Sgk1 gene modified to introduce an activating point mutation. Wild type or transgenic 14-week-old male mice were fed with standard chow diet or high-fat diet for up to 18 weeks. Development of the main features of MetS and hepatic steatosis were monitored, and in vitro adipocyte differentiation was studied. Our results show that transgenic animals under high-fat diet rapidly and markedly develop MetS characterized by obesity, glucose intolerance, insulin resistance, dyslipidemia and hypertension. In addition, SGK1 gain-of-function accelerates the development of hepatic steatosis. Our study suggests that inappropriate SGK1 activity represents a risk factor in developing MetS with hypertension and related end-organ damage. Our data support SGK1 as a possible therapeutic target in MetS and related complications and provides a useful gain-of-function model for pre-clinical drug testing.
\end{abstract}

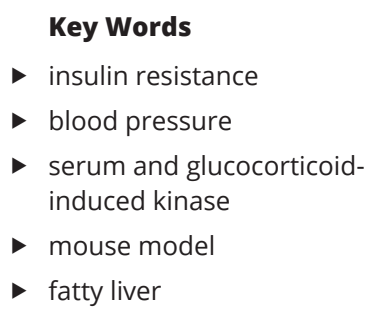

Journal of Endocrinology (2020) 244, 149-162

\section{Introduction}

SGK1 is a ubiquitously expressed AGC kinase initially characterized in rat mammary tumor cells as an immediate early gene induced by serum and glucocorticoids (Webster et al. 1993). Its expression is also upregulated by aldosterone (Chen et al. 1999, Naray-Fejes-Toth et al. 1999) and other factors including glucose (Lang et al. 2006). Once synthesized, SGK1 is activated by insulin and several growth factors through phosphoinositide 
3-kinase, PDK1 and mTORC2 (Garcia-Martinez \& Alessi 2008). Genetic and pharmacological approaches revealed that SGK1 participates in numerous physiological and pathophysiological processes. Excess activation of SGK1 triggers pro-fibrotic and pro-inflammatory processes (Artunc \& Lang 2014). SGK1 phosphorylates signaling molecules such as GSK3 $\beta$ and promotes cell survival and proliferation by phosphorylating the FOXO family of transcription factors (Brunet et al. 2001). SGK1 has an important role enhancing transepithelial $\mathrm{Na}^{+}$reabsorption (Chen et al. 1999, Naray-Fejes-Toth et al. 1999, Wulff et al. 2002) and controlling blood pressure (Pearce 2003, Verrey et al. 2003, Norlander et al. 2017). SGK1-knockout mice have normal blood pressure, but are protected against saltdependent hypertension in the context of a high-fat diet (Huang et al. 2006b). In addition, SGK1 polymorphisms associate to increased blood pressure in humans (Busjahn et al. 2002), making carriers more susceptible to blood pressure increase associated to hyperinsulinemia (von Wowern et al. 2005). Recent studies show that SGK1 regulates adipocyte differentiation and is expressed in white adipose tissue (Di Pietro et al. 2010). The importance of SGK1 in metabolism is further supported by studies showing that an SGK1 inhibitor reduces blood pressure and body weight in hyperinsulinemic mice (Ackermann et al. 2011) and counteracts obesity and hyperglycemia in $d b / d b$ mice (Li et al. 2016). Finally, SGK1 polymorphisms in humans (E8CC/CT; I6CC) associate with obesity (Dieter et al. 2004) and diabetes (Schwab et al. 2008). In summary, multiple lines of evidence point to the serum and glucocorticoid-regulated kinase 1 (SGK1) as a common pathway impacting the development of cardiovascular risk factors such as metabolic disturbances and hypertension.

To date, the effects of excess SGK1 activity on hypertension, obesity and glucose homeostasis has not been studied. To test whether excess SGK1 activity synergically activates pathways leading to hypertension and metabolic alterations, we took advantage of the gain-of-function transgenic $S g k 1$ mouse model (Tg.sgk1) previously developed in our laboratory (Andres-Mateos et al. 2013, Miranda et al. 2013) in combination with the high-fat diet (HFD)-induced model of obesity and glucose intolerance. Our results demonstrated exacerbated body weight gain due to fat accumulation, adipocyte hypertrophy, dyslipidemia and hyperinsulinemia, prominent glucose and insulin intolerance and a rapid development of hypertension and fatty liver.

\section{Materials and methods}

\section{Mouse model with constitutively active SGK1 expression}

Experimental procedures involving mice were approved by the University of La Laguna Ethics Committee on Research and Animal Welfare (permit no. CEIBA2016-0197) and were performed in accordance with Spanish and European Union regulations (RD53/2013 and 2010/63/EU, respectively). Generation of transgenic mice expressing a constitutively active mutant of SGK1 (Tg.sgk1) under its own promoter has been previously described (AndresMateos et al. 2013, Miranda et al. 2013). Briefly, a bacterial artificial chromosome (BAC) containing $180 \mathrm{kbp}$ of mouse genomic DNA that includes the full $S g k 1$ gene but no other known or predicted genes was obtained from the BACPAC Resources Center (Children's Hospital Oakland Research Institute, Oakland, CA, USA). The BAC was modified by homologous recombination in $E$. coli to introduce point mutation S422D, which renders the kinase constitutively active (Kobayashi \& Cohen 1999). The purified BAC insert was used for pronuclear injection of $(\mathrm{C} 57 \mathrm{BL} / 6 \mathrm{~J} \times \mathrm{SJL} / \mathrm{J}) \mathrm{F} 2$ embryos. Founder animals harboring the transgene were backcrossed with C57BL/6 mice for nine generations to produce the B6.Tg.sgk1 line. Mice homozygous for the transgene were obtained by crossing heterozygous animals.

\section{Animal procedures}

Mice were kept in a 14 -h light/10-h dark cycle at $22^{\circ} \mathrm{C}$ with ad libitum access to food and water. Mice were fed a standard chow diet (SCD; Teklad Global Rodent Diet 2014s; $2.9 \mathrm{kcal} / \mathrm{g}, 13 \%$ calories from fat; $4 \%$ fat, $66 \%$ carbohydrates, and $14.3 \%$ proteins). Twelve-week-old male mice were fed either SCD or high-fat diet (HFD; Research Diets 12,492; $5.24 \mathrm{kcal} / \mathrm{g}, 60 \%$ calories from fat; $34.9 \%$ fat, $26.3 \%$ carbohydrate, $26.2 \%$ protein) for the time indicated in each experiment. Food intake and body weight (BW) were measured weekly in mice housed in grouped cages. To study body composition mice were fasted $3 \mathrm{~h}$, anesthetized by intraperitoneal injection of ketamine $(37.5 \mathrm{mg} / \mathrm{kg})$ combined with medetomidine $(0.5 \mathrm{mg} / \mathrm{kg})$ and examined by dual-energy X-ray absorptiometry (DEXA; Lunar PIXImus apparatus, GE Medical Systems); anesthesia was reverted with atipamezole $(1 \mathrm{mg} / \mathrm{kg})$. Glucose tolerance tests (GTTs) were performed on animals fasted overnight and injected intraperitoneally with a glucose bolus ( $2 \mathrm{~g} / \mathrm{kg} \mathrm{BW})$. Glycemia was measured before $(t=0)$ and 5, 15, 30, 45, 60, 90 and 120 min after https://joe.bioscientifica.com https://doi.org/10.1530/JOE-19-0275 (c) 2020 Society for Endocrinology Published by Bioscientifica Ltd. Printed in Great Britain 
injection on blood samples obtained by tail massage using a commercial glucometer (OneTouch Ultra, Johnson \& Johnson). Insulin tolerance tests (ITTs) were performed on unfasted mice. Insulin was injected intraperitoneally $(0.75 \mathrm{U} / \mathrm{kg} \mathrm{BW})$ and blood glucose measurements were performed as in GTT. Insulinemia was measured using a commercial mouse ELISA Kit (Mercodia). Insulin resistance was assessed using the homeostasis model assessment (HOMA-IR) (Muniyappa et al. 2008). Insulin sensitivity was assessed by the quantitative insulin sensitivity check index (QUICKI) (Pacini et al. 2013, Bowe et al. 2014). Systolic blood pressure (SBP) was measured in trained conscious mice by tail-cuff plethysmography (LE5007, Panlab Harvard Apparatus) using SeDaCom 2.0 software. Measurements were collected for three consecutive days after 5 days of training. SBP was measured at 20-min intervals for $1 \mathrm{~h}$ between 10:00 and 11:00 h Mice were killed by cervical dislocation.

\section{Plasma and liver biochemistry}

At the time of death, blood samples were collected by cardiac puncture in $1.5 \mathrm{~mL}$ tubes with $150 \mu \mathrm{L} 5 \mathrm{mM}$ EDTA or heparin (in the case of cholesterol determinations) and plasma was obtained by centrifugation. Samples were assayed for total insulin (ultrasensitive mouse insulin ELISA Kit, Mercodia), total, HDL and LDL/VLDL cholesterol (cholesterol assay kit, Abcam), triglycerides (triglyceride quantification kit, Abcam), glucose and FFA (FFA quantification Kit, Abcam). Liver triglycerides content was measured using a commercial kit (Abcam).

\section{Tissue sampling and histology}

At killing, fat depots and liver were dissected and weighed. Organs were frozen in liquid nitrogen and stored at $-80^{\circ} \mathrm{C}$ for molecular analysis or fixed by immersion in $4 \%$ formaldehyde, paraffin-embedded and processed for histology. Microtome $5 \mu \mathrm{m}$-thick sections were stained with hematoxylin-eosin reagent. Sections were coded for unbiased examination. Liver steatosis was evaluated using a semiquantitative scale adapted from previously validated procedures (Kleiner et al. 2005). To that end, images from three different fields in each section were collected at 20x magnification and assigned a value in a four-point scale $(0$, no intracellular lipid drops detected; 1, 2 and 3, progressively increased abundance of lipid drops; Fig. 4).

\section{Gene expression analysis}

Total RNA was extracted from tissues or cells using a commercial kit that includes in-column DNA digestion (Total RNA spin plus, REAL, Valencia, Spain) and quantified using a Nanodrop 1000 (ThermoFisher Scientific). Relative mRNA abundance was assessed by quantitative RT-PCR (qPCR) using the comparative $\mathrm{C}_{\mathrm{t}}$ method with RPL13A mRNA expression as normalizer. Optimal annealing temperatures and efficiency were determined for each primer pair. Primers used in this study are listed in Table 1.

\section{Western blot}

Protein extracts were obtained from frozen tissue or cells and quantified using the bicinchoninic acid procedure (Sigma). Equal amounts of protein were resolved on SDS-PAGE (10\% Mini-PROTEAN® TGX Stain-Free ${ }^{\mathrm{TM}}$ Gels, BioRad) and transferred to polyvinylidene difluoride membranes (Trans-Blot ${ }^{\circledR}$ Turbo ${ }^{\mathrm{TM}}$ Mini PVDF Transfer Packs BioRad). Western blot analysis was performed as previously described (Andres-Mateos et al. 2013) using the antibodies listed in Table 2. Signals were acquired with

Table 1 Primers used in this study.

\begin{tabular}{ll}
\hline Gene & Forward \\
\cline { 1 - 2 } Sgk1 & CGGTTTCACTGCTCCCCTCAG \\
$/ 11$ & TGGACAAACACTATCTCAGCA \\
$1 / 6$ & TCTCTGGGAAATCGTGGAAA \\
Tnf $\alpha$ & CCCCAAAGGGATGAGAAGTT \\
Cd68 & AAAGGCCGTTACTCTCCTG \\
Mcp1 & GTCACCAAGCTCAAGAGAGA \\
Glut4 & ACACTGGTCCTAGCTGTATTCT \\
Cd36 & GATGACGTGGCAAAGAACAG \\
Ppary & TTCACAAGAGCTGACCCAAT \\
Cebp $\alpha$ & GACAAGAACAGCAACGAGTA \\
Lpl & GGAGGTGGACATCGGAGAAC \\
Adiponectin & TGCCGAAGATGACGTTACTA \\
\hline
\end{tabular}

\begin{tabular}{l}
\hline Reverse \\
\hline GCGATGAGAATCGCTACCATT \\
GAGTTTTGTGTTTCTGGCA \\
CCAGGTAGCTATGGTACTCC \\
TCTTTGAGATCCATGCCGTT \\
TGTGGCATGAGAAATTGTGG \\
GTGGAAAAGGTAGTGGATGC \\
CCAGCCACGTTGCATTGTA \\
TCCTCGGGGTCCTGAGTTAT \\
AAGCCTGATGCTTTATCCCC \\
AGCTGGCGGAAGATGC \\
ACACTGCTGAGTCCTTTCCC \\
TCTCACCCTTAGGACCAAGA
\end{tabular}




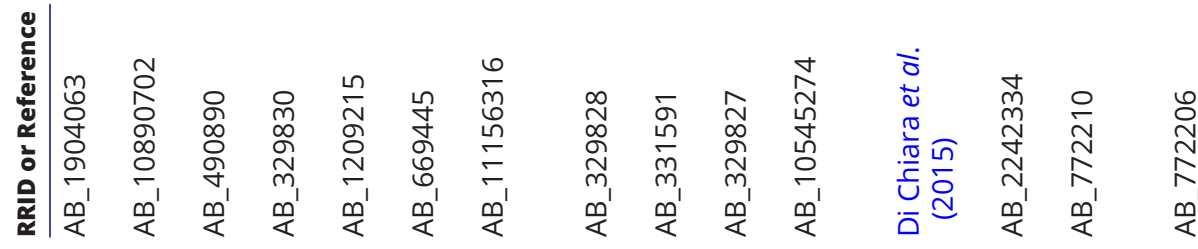

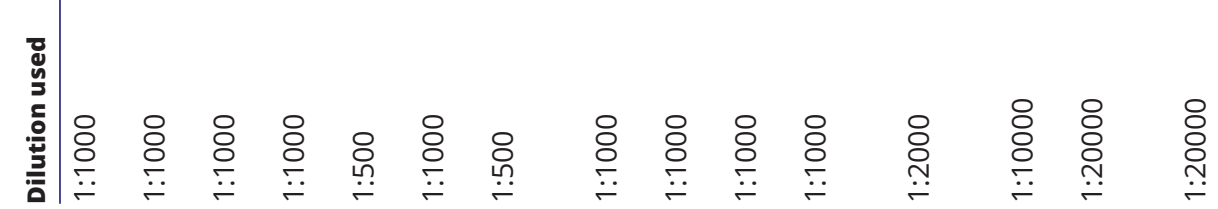

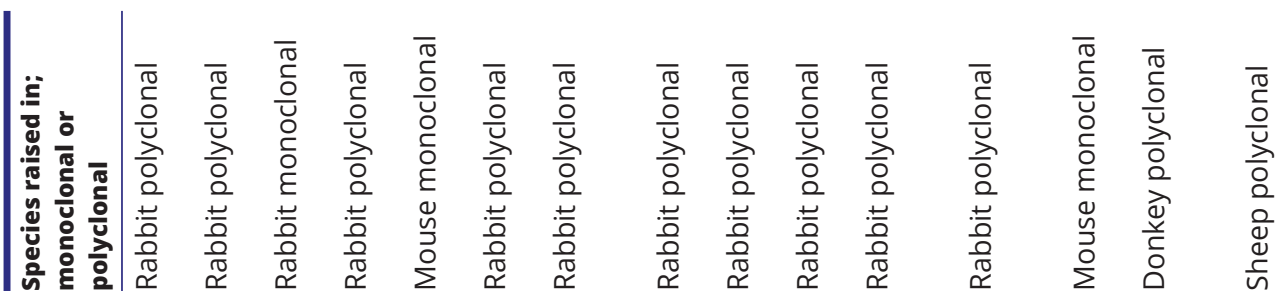
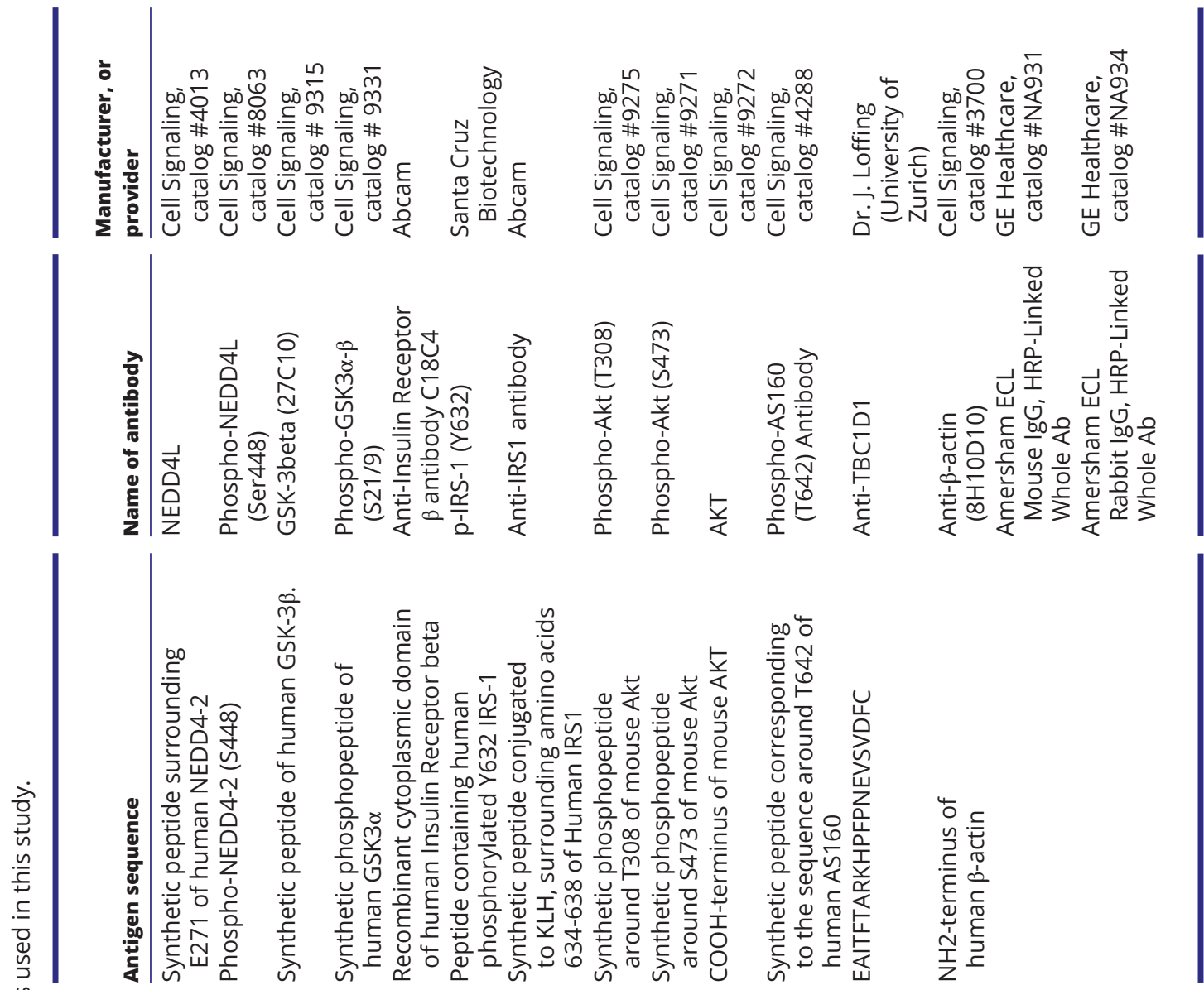

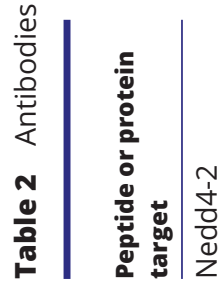

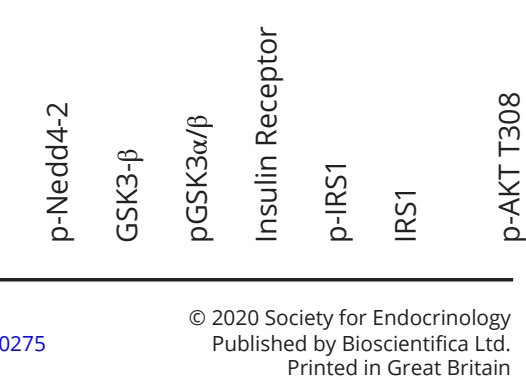


luminesce detector (ChemiDoc ${ }^{\mathrm{TM}}$ Touch Imaging System, BioRad) and quantified using software provided by the manufacturer.

\section{In vitro pre-adipocyte differentiation}

Vascular stromal cell fraction from WT or Tg.sgk1 mice was prepared from pooled fat pads (inguinal, axillar, epididymal and perirenal) and cultured as described (Desarzens \& Faresse 2016). Cells were allowed to reach confluence and the differentiation process was initiated using DMEM supplemented with $10 \%$ fetal bovine serum (FBS) $500 \mu \mathrm{M}$ 3-isobutyl-1-methylxanthine, $1 \mu \mathrm{g} / \mathrm{mL}$ insulin, $250 \mathrm{nM}$ dexamethasone and $2 \mu \mathrm{M}$ rosiglitazone for 2 days. Cells were then grown in DMEM supplemented with 10\% FBS, $1 \mu \mathrm{g} / \mathrm{mL}$ insulin for an additional 2 days. Experiments were performed once the cells were fully differentiated (around day 20) and clear lipid droplets were observed. For determination of lipid content, cells were fixed in $4 \%$ paraformaldehyde in PBS, washed twice with water and once with $60 \%$ isopropanol, and stained with Oil-Red-O. After excess Oil-Red-O removal and washes with water, the stained cells were permeabilized with 100\% isopropanol and $10 \%$ SDS and Oil-Red-O in the eluate was measured by spectrophotometry at $520 \mathrm{~nm}$.

\section{Glucose and FFA uptake}

Undifferentiated and differentiated adipocytes from WT and B6.Tg.sgk1 mouse were cultured for $24 \mathrm{~h}$ without serum. Cells were washed with Krebs-Ringer buffer containing $12 \mathrm{mM}$ HEPES and 0.1\% BSA (KRH-BSA) and then treated with $100 \mathrm{nM}$ insulin for $30 \mathrm{~min}$. Glucose uptake was initiated by addition of $1 \mu \mathrm{Ci}$ /well of $\left[{ }^{3} \mathrm{H}\right]$-deoxy-D-glucose. After 5-min incubation cells were washed three times with ice-cold KRH-BSA. FFA uptake was initiated by addition of $1 \mu \mathrm{Ci} /$ well of $\left[1-{ }^{14} \mathrm{C}\right]$-palmitic acid for $5 \mathrm{~min}$ and stopped by washing cells three times with ice-cold KRH-BSA. In both cases, cells were then lysed with $0.1 \mathrm{M} \mathrm{NaOH}$ and radioactivity was measured by scintillation counting. In parallel, protein concentration in each sample was measured using the Bradford method.

\section{Statistical analysis}

Data are reported as average \pm s.e. Statistical analysis was performed with Prism 7 software (GraphPad). Statistical tests used for analysis are specified in each figure legend.

\section{Results}

\section{Constitutively active SGK1 expression exacerbates HFD-induced obesity, adipocyte hypertrophy and inflammation}

To test the effects of constitutive SGK1 activation on HFD-induced obesity, we fed 14-week-old wild type (WT) or Tg.sgk1 mice either with a standard chow diet (SCD) or a high-fat diet (HFD) for up to 6 weeks. At the end of this period mice fed SCD did not show any difference in total body weight, although Tg.sgk1 had a higher fat content, suggesting a predisposition to obesity (Table 3).

Table 3 Plasma biochemistry and glucose homeostasis indexes in animals fed standard chow diet (SCD) or after 6 weeks with high-fat diet (HFD).

\begin{tabular}{|c|c|c|}
\hline \multirow[b]{2}{*}{ Variable (units) } & \multicolumn{2}{|c|}{ SCD } \\
\hline & WT & Tg.sgk1 \\
\hline Body weight (g) & $25.49 \pm 0.38 ; n=50$ & $24.94 \pm 0.48 ; n=56$ \\
\hline Lean tissue (g/BW) & $0.41 \pm 0.01 ; n=6$ & $0.38 \pm 0.01 ; n=6$ \\
\hline Fat tissue (g/BW) & $0.24 \pm 0.00 ; n=6$ & $0.31 \pm 0.02 \mathrm{a} ; n=6$ \\
\hline $\begin{array}{l}\text { Non-fasting insulin } \\
(\mathrm{ng} / \mathrm{mL})\end{array}$ & $0.44 \pm 0.07 ; n=8$ & $0.48 \pm 0.10 ; n=6$ \\
\hline Fasting insulin (ng/mL) & $0.08 \pm 0.04 ; n=7$ & $0.04 \pm 0.03 ; n=7$ \\
\hline Fasting glucose $(\mathrm{mg} / \mathrm{dL})$ & $97.6 \pm 4.7 ; n=7$ & $129.0 \pm 7.9 a ; n=11$ \\
\hline HOMA-IR & $0.4 \pm 0.2 ; n=7$ & $0.3 \pm 0.2 ; n=7$ \\
\hline QUICKI & $0.55 \pm 0.13 ; n=7$ & $0.82 \pm 0.16 ; n=7$ \\
\hline T-Cholesterol (mg/mL) & $62.86 \pm 5.9 ; n=6$ & $68.14 \pm 10.25 ; n=6$ \\
\hline $\mathrm{HDL}-\mathrm{C}(\mathrm{mg} / \mathrm{mL})$ & $59.6 \pm 2.3 ; n=6$ & $45.7 \pm 4.0 ; n=6$ \\
\hline VLDL-C (mg/mL) & $2.5 \pm 0.6 ; n=6$ & $5.7 \pm 1.0 ; n=6$ \\
\hline Triglycerides (mg/dL) & $52.3 \pm 8.0 ; n=6$ & $84.8 \pm 12.9 ; n=6$ \\
\hline FFAs (mmol/dL) & $7.8 \pm 1.0 ; n=6$ & $8.8 \pm 0.4 ; n=6$ \\
\hline
\end{tabular}

\begin{tabular}{|c|c|}
\hline \multicolumn{2}{|c|}{ HFD } \\
\hline WT & Tg.sgk1 \\
\hline $31.51 \pm 0.77 ; n=50$ & $34.83 \pm 0.76 a ; n=56$ \\
\hline $0.58 \pm 0.02 ; n=31$ & $0.50 \pm 0.01 a ; n=35$ \\
\hline $0.31 \pm 0.02 ; n=31$ & $0.44 \pm 0.01 \mathrm{~b} ; n=35$ \\
\hline $1.66 \pm 0.15 ; n=6$ & $5.51 \pm 0.88 a ; n=6$ \\
\hline $0.17 \pm 0.03 ; n=7$ & $1.09 \pm 0.23 a ; n=11$ \\
\hline $158.0 \pm 4.8 ; n=7$ & $200.2 \pm 14.4 \mathrm{c} ; n=10$ \\
\hline $1.7 \pm 0.3 ; n=7$ & $13.2 \pm 2.9 \mathrm{~b} ; n=11$ \\
\hline $0.32 \pm 0.01 ; n=7$ & $0.26 \pm 0.00^{\mathrm{b}} ; n=12$ \\
\hline $110.8 \pm 5.6 ; n=6$ & $108.6 \pm 2.9 ; n=6$ \\
\hline $114.5 \pm 3.6 ; n=6$ & $91.4 \pm 7.7^{\mathrm{b}} ; n=6$ \\
\hline $3.1 \pm 1.0 ; n=6$ & $4.2 \pm 0.5 ; n=6$ \\
\hline $82.8 \pm 9.8 ; n=6$ & $123.7 \pm 11.7 c ; n=6$ \\
\hline $7.0 \pm 0.8 ; n=6$ & $8.0 \pm 0.5 ; n=6$ \\
\hline
\end{tabular}

Results are expressed as average \pm S.E. ( $n$, number of animals; $\mathrm{a} P<0.01, \mathrm{~b} P<0.001, \mathrm{c} P<0.05$; unpaired $t$ tests between genotypes in SCD or HFD). BW, body weight; FFAs, free fatty acids; HDL-C, high-density lipoprotein cholesterol; HOMA, homeostatic model assessment; QUICKI, quantitative insulin sensitivity check index; T-Cholesterol, total cholesterol; VLDL-C, very low-density lipoprotein cholesterol.

\begin{tabular}{|lr} 
https://joe.bioscientifica.com & (c) 2020 Society for Endocrinology \\
https://doi.org/10.1530/JOE-19-0275 & Published by Bioscientifica Ltd. \\
Printed in Great Britain
\end{tabular}


HFD induced a faster weight gain in transgenics when compared to WT mice (Fig. 1A). The dramatic increase of BW gain in transgenic mice fed with HFD was not due to hyperphagia since food intake was even lower than WT mice (Fig. 1B). The observed BW differences were due to fat accumulation, as determined by DEXA (Fig. 1C and Table 3) or by individual dissection of fat pads (Fig. 1D). Histological analysis of epididymal adipose tissue revealed prominent adipocyte hypertrophy after 6 weeks of HFD in transgenic animals when compared to WT, with fewer adipocytes/area (Fig. 1E) and adipocyte area frequency distribution skewed toward larger values (Fig. 1F). Quantitative analysis of mRNA expression showed that white adipose tissue displays increased expression of SGK1, which is expected due to the increase gene dosage provided by the BAC insertion (Fig. 1G). Endogenously expressed Nedd4-2, a wellknown SGK1 target (Debonneville et al. 2001), showed increased phosphorylation in white adipose tissue from Tg.sgk1 mice when compared to WT, consistent with the expression of a constitutively active SGK1 (Fig. $1 \mathrm{H})$. Adipocyte hypertrophy contributes to unfavorable metabolic changes (Sun et al. 2011). To test whether fat pad expansion and adipocyte hypertrophy correlated with increased inflammation, we analyzed expression of inflammation markers in epididymal fat. No difference between WT and Tg.sgk1 mice was observed under SCD (Fig. 1I). HFD increased expression of all inflammation markers in both WT and Tg.sgk1 mice (Fig. 1I). However, Tg.sgk1 mice showed significantly higher expression of IL-6, TFN $\alpha$ and MCP-1, suggesting increased adipose tissue inflammation.

\section{Constitutive activation of SGK1 promotes insulin-induced glucose and free fatty acids (FFAs) uptake in primary adipocytes}

To test whether adipocyte hypertrophy observed in Tg.sgk1 mice was due to increased nutrient uptake, we measured glucose and FFA uptake in vitro using differentiated adipocytes from adipose vascular stromal cells. Insulin-induced glucose and FFA uptake was higher in differentiated adipocytes derived from transgenic mice (Fig. 2A and B). At the molecular level, glucose transporter GLUT4 and lipid transporter CD36 expression levels were also significantly higher in cells derived from Tg.sgk1 mice (Fig. 2C and D), suggesting that SGK1 activation promotes adipocyte differentiation and lipid accumulation. This hypothesis was confirmed by the higher lipid accumulation (Fig. 2E and F) and adipogenesis marker expression (Fig. 2G) in cells derived from transgenic mice. Taken together, these data indicate that increased expression of SGK1 enhances adipogenesis and increases uptake of FFAs and glucose, possibly by upregulating membrane transporters.

\section{Dyslipidemia, glucose intolerance and insulin resistance in HFD-fed Tg.sgk1 mice}

Adipocyte hypertrophy and low-grade inflammation are closely associated with the development of dyslipidemia and insulin resistance (Shoelson et al. 2006, Kim et al. 2015). To investigate whether the exacerbated obese phenotype observed in Tg.sgk1 mice correlated with larger metabolic disturbances, several metabolic parameters were measured in the plasma of SCD- or HFD-fed WT and Tg.sgk1 mice. Under fed conditions, HFD-fed transgenic mice showed significantly higher levels of insulin and triglycerides and decreased levels of HDL cholesterol (Table 3). Under fasting condition, Tg.sgk1 maintained their hyperinsulinemia as well as hyperglycemia (Table 3). In addition, SCD-fed transgenics also show increased fasting glucose (Table 3) and a positive correlation between glycemia and BW (Fig. $3 \mathrm{~A})$, suggesting an impairment of glucose homeostasis that is exacerbated under HFD. Accordingly, transgenic animals displayed a significantly impaired response to a glucose challenge after 5 weeks in HFD (Fig. 3B and C). ITT revealed that after 6 weeks in HFD Tg.sgk1 mice show decreased sensitivity to insulin (Fig. 3D and E). In agreement with these observations, HOMA index was increased in Tg.sgk1 compared to WT mice (Table 3). Transgenics also displayed decreased QUICKI values (Table 3). Analysis of insulinemia during GTT showed that glucose-stimulated insulin secretion was affected in Tg.sgk1 mice (Fig. 3F and G). This indicates that transgenic animals with excess SGK1 and fed a HFD are insulin resistant with advanced diabetic features.

Insulin resistance was further confirmed by studying the insulin signaling pathway in epididymal adipose tissue of HFD-fed animals. Despite significantly increased insulin receptor expression, Tg.sgk1 mice showed a significant reduction in phosphorylation of downstream effectors IRS1, protein kinase AKT and its substrate AS160 (Fig. $3 \mathrm{H}$ and I). This observation confirmed that defects responsible for insulin resistance occurred at the postreceptor level as previously described (Kolterman et al. 1980, Draznin 2006). https://joe.bioscientifica.com https://doi.org/10.1530/JOE-19-0275 (c) 2020 Society for Endocrinology Published by Bioscientifica Ltd.
Printed in Great Britain 


\begin{tabular}{l|l|l|l|l|}
$\begin{array}{l}\text { Journal of } \\
\text { Endocrinology }\end{array}$ & $\begin{array}{l}\text { C Sierra-Ramos, } \\
\text { S Velázquez-García et al. }\end{array}$ & $\begin{array}{l}\text { SGK1 and metabolic syndrome } \\
\text { development }\end{array}$ & $\mathbf{2 4 4 : 1}$ & $\mathbf{1 5 5}$ \\
\hline
\end{tabular}

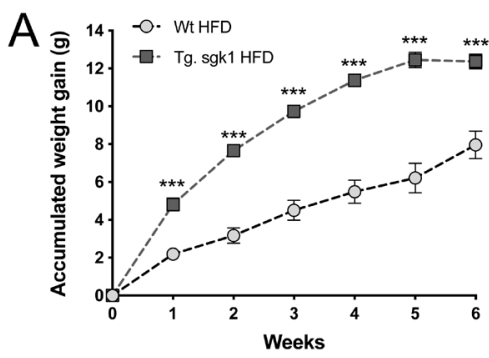

C

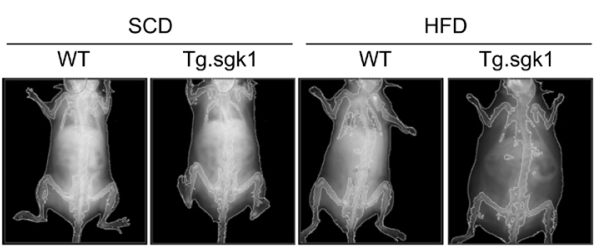

B
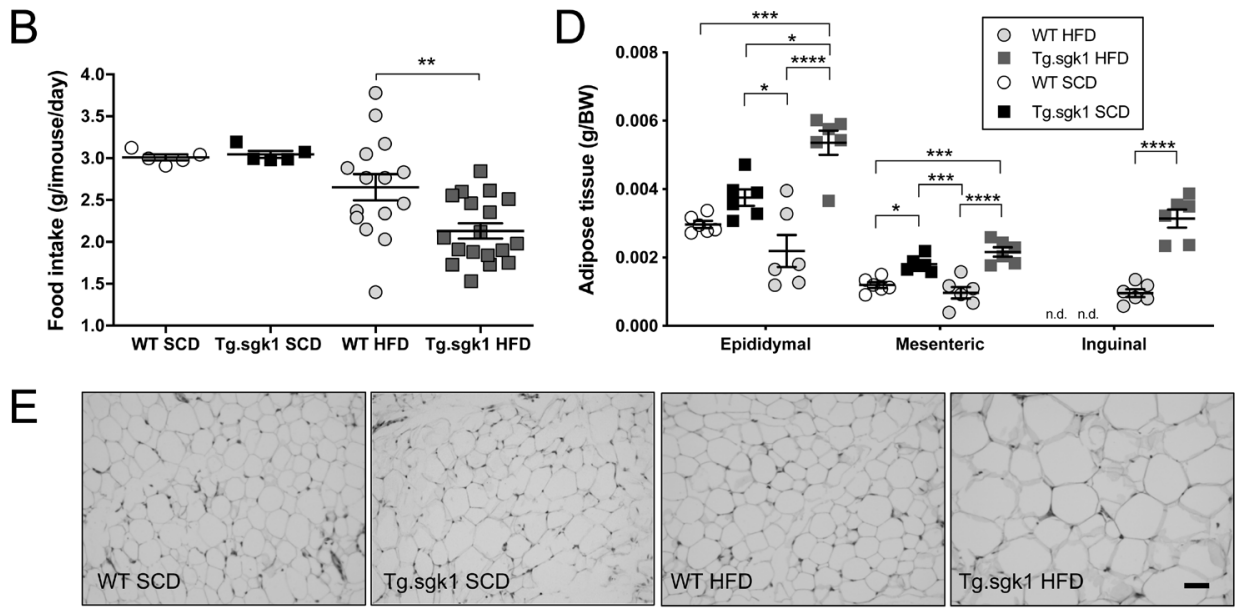

F

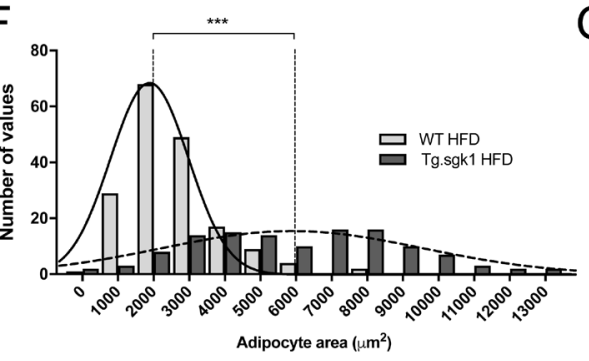

G

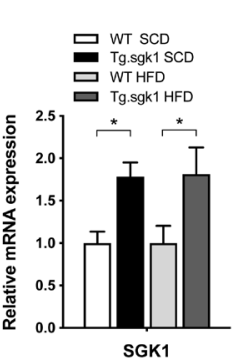

$\mathrm{H}$

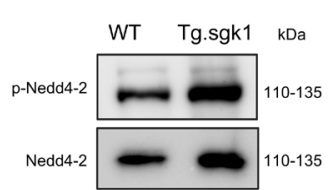

I

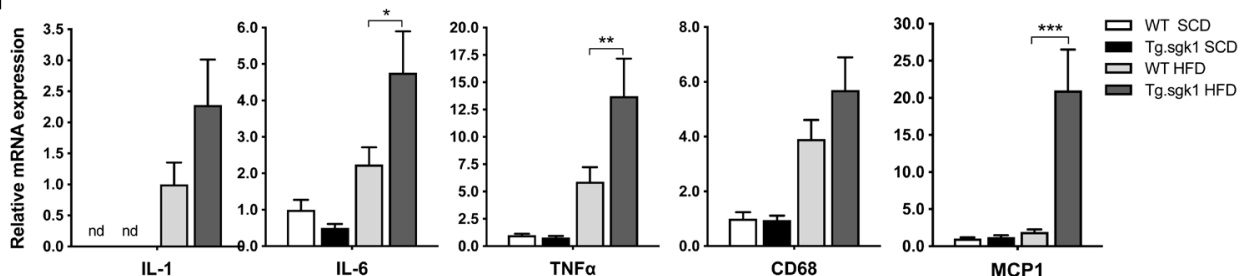

Figure 1

Constitutively active SGK1 exacerbates diet-induced obesity, adipocyte hypertrophy and adipose tissue inflammation. (A) BW variation in age-matched WT or Tg.sgk1 mice fed with a high-fat diet (HFD). Data points represent average weekly cumulative weight gain \pm s.E. $(n=39$ for WT; $n=43$ for Tg.sgk1). Two-way ANOVA followed by Tukey's multiple comparison test ( $* P<0.05$, $* * * P<0.001$ ). (B) Average \pm S.E.M. food intake/day in animals fed with SCD or HFD ( $n=5$ for SCD; $n=15$ for WT HFD group; $n=18$ for Tg.sgk1 HFD; ** $P<0.01$, Student's $t$ test). (C) Representative images of body composition analysis by DEXA in anesthetized mice. (D) Average epididymal and mesenteric adipose tissue weight \pm S.E.M. $(n=6)$ normalized to total body weight of WT and Tg.sgk1 mice kept on SCD or after 6 weeks on HFD ( ${ }^{*} P<0.05, * \star * P<0.001$, $* \star \star * P<0.0001$, one-way ANOVA followed by Tukey's multiple comparison test). The weight of inguinal fat in mice kept in SCD was not determined (n.d.). (E) Representative micrographs of hematoxylin-eosin-stained epididymal white adipose tissue obtained from WT or Tg.sgk1 mice kept under SCD or fed a HFD for 6 weeks. Bar, $40 \mu \mathrm{m}$. (F) Frequency histogram with Gaussian distribution fit showing percentage of adipocytes from HFD-fed animals in each area category $(n=6)$. Dashed lines, median values for WT and Tg.sgk1 adipocyte area. $* \star \star P<0.001$, Mann-Whitney test. (G) SGK1 mRNA expression in epididymal fat of WT and Tg.sgk1 mice under SCD or HFD. Values represent average \pm S.E.M. $(n=6)$. $* P<0.05$, one-way ANOVA followed by Sidak's multiple comparison test. (H) Representative immunoblot detecting total and phospho-S488 Nedd4-2 in protein extracts obtained from epididymal fat of WT or Tg.sgk1 mice. (I) Relative mRNA expression of inflammation markers in epididymal fat of WT and Tg.sgk1 mice under SCD or HFD. Values represent average \pm S.E.M. $(n=6)$. CD68, cluster of differentiation 68; IL-1, interleukin 1; IL-6, interleukin 6; MCP1, monocyte chemoattractant protein-1; nd, non-detectable; TNF $\alpha$, tumor necrosis factor $\alpha .{ }^{*} P<0.05$, $\star \star * P<0.01$, one-way ANOVA followed by Sidak's multiple comparison test. 

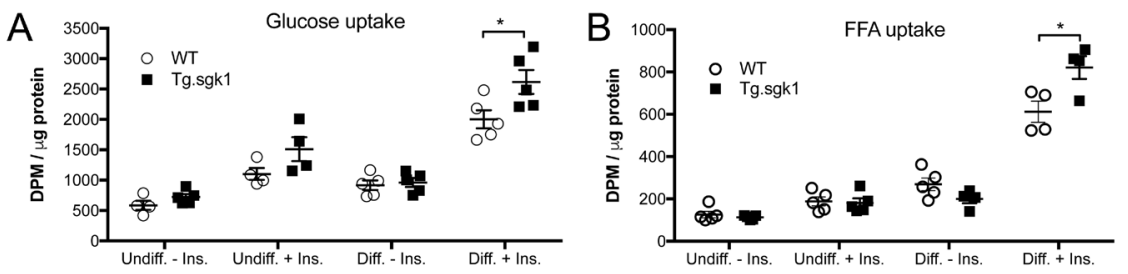
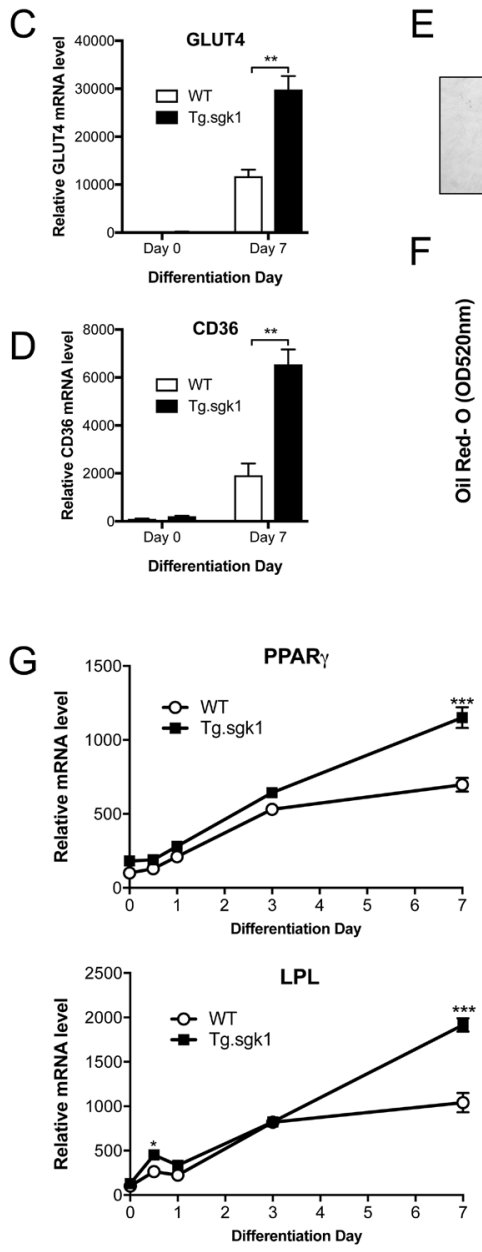

$\mathrm{F}$
E Undifferentiated Differentiated
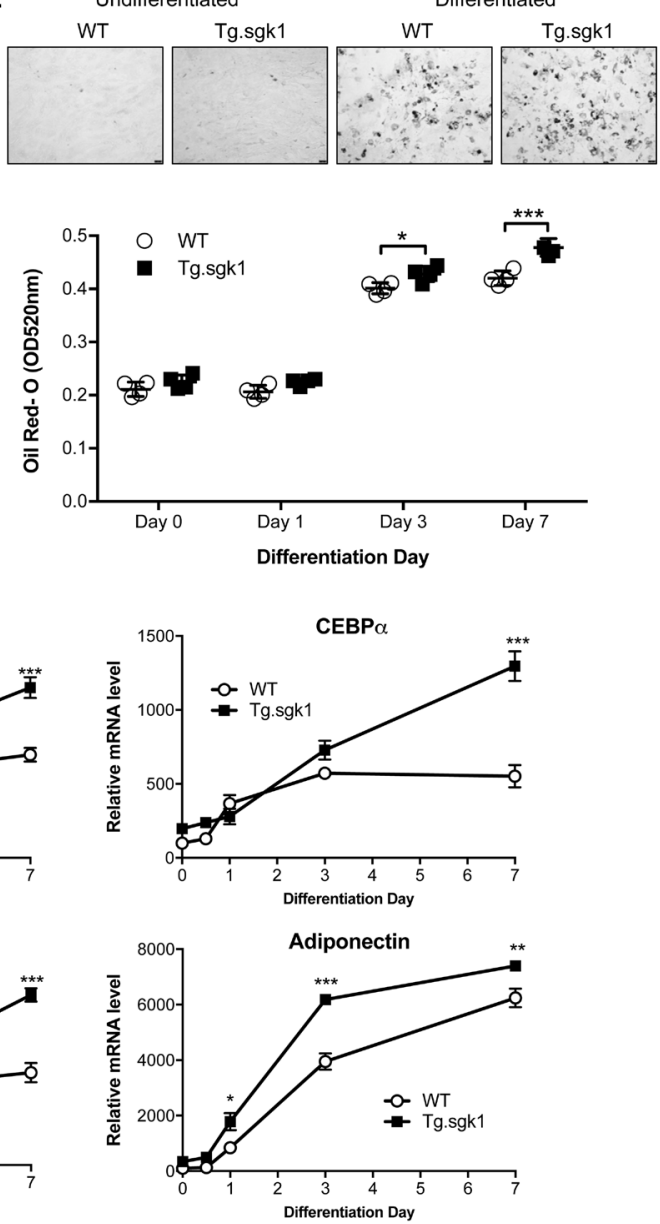

Figure 2

Increased SGK1 increases glucose and free fatty acids (FAAs) uptake and accelerates in vitro adipocyte differentiation. Basal and insulininduced glucose (A) or FAA (B) uptake in undifferentiated and differentiated adipocytes obtained from WT or Tg.sgk1 mice. Bars represent average \pm S.E.M. $(n=4)$ incorporated radioactivity normalized to protein concentration. Student's t test, $* P<0.05$. Glucose transporter GLUT4 (C) and lipid transporter CD36 (D) mRNA expression at Day 0 and Day 7 during differentiation. Values are average \pm S.E.M. $(n=4)$. Student's $t$ test; $* * P<0.01$. (E) Oil red-O accumulation in undifferentiated or differentiated cells. (F) Symbols represent individual oil red-O absorbance values at $520 \mathrm{~nm}$ from four independent experiments; $* P<0.05$; $\star \star \star x<0.001$ (two-way ANOVA followed by Sidak's multiple comparison test). (G) Lipogenic marker expression during differentiation. Values are average \pm S.E.M. normalized to RPL13A. CEBP $\alpha$, CCAAT-enhancer binding protein $\alpha$; LPL, lipoprotein lipase; PPAR $\gamma$, peroxisome proliferator activated receptor $\gamma$. Two-way ANOVA followed by Sidak's multiple comparison test: $* P<0.05$; $\star \star P<0.01 ; * * \star P<0.001$

\section{Non-alcoholic fatty liver (NAFL) in HFD-fed Tg.sgk1 mice}

In order to check whether the metabolic disorders induced by HFD in Tg.sgk1 mice accelerates the development of NAFL, we analyzed lipid accumulation by histological analysis of liver sections. We first confirmed increased SGK1 expression in the liver of transgenics. Total SGK1 mRNA abundance was increased by $60 \%$ in Tg.sgk 1 compared to WT mice under SCD (Fig. 4A). Tg.sgk1 mice treated with HFD showed 2.8-fold increased expression of SGK1, suggesting that constitutively active SGK1 may potentiate its own expression under these conditions (Fig. 4A).
Phosphorylation of a well-known downstream target of SGK1, glycogen synthase kinase 3 (GSK3) (Wyatt et al. 2006), was also increased in Tg.sgk1 (Fig. 4B). Hematoxylin-eosin staining revealed that after 6 weeks of HFD Tg.sgk1 livers presented severe micro- and macrovesicular steatosis with marked hepatocellular ballooning, while WT mice presented less affected livers with microvesicular steatosis only. Semiquantitative analysis of the extent of lipid inclusion supported widespread presence of NAFL in HFD-fed Tg.sgk1, but not in WT animals (Fig. 4C and D). Biochemical analysis of liver tissue composition confirmed the significantly higher triglycerides content in Tg.sgk1 mice livers (Fig. 4E). https://joe.bioscientifica.com https://doi.org/10.1530/JOE-19-0275
(C) 2020 Society for Endocrinology Published by Bioscientifica Ltd. Printed in Great Britain 
A

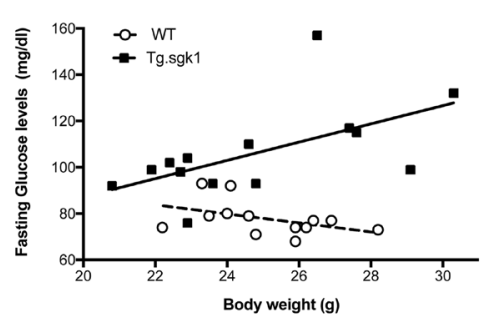

D

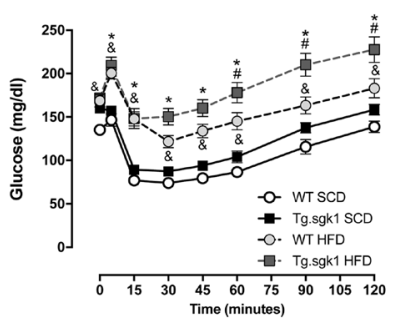

G

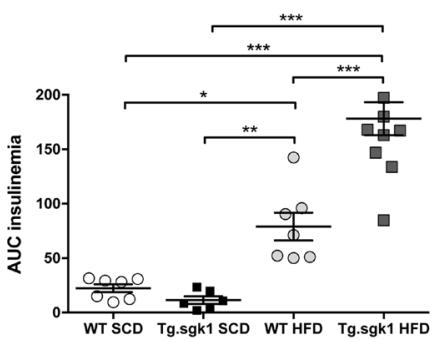

B

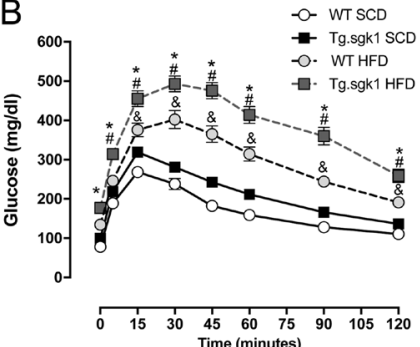

E

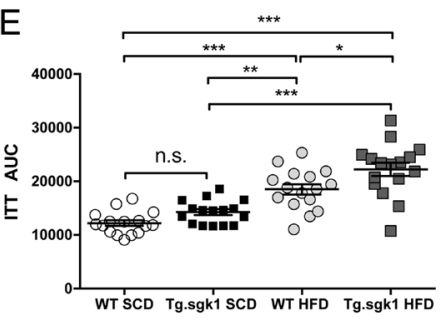

$\mathrm{H}$

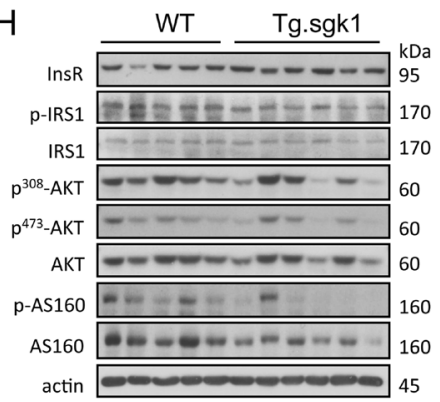

C

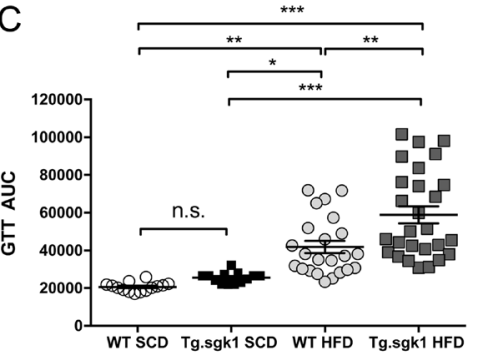

F

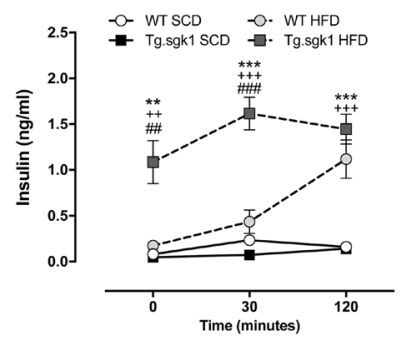

I

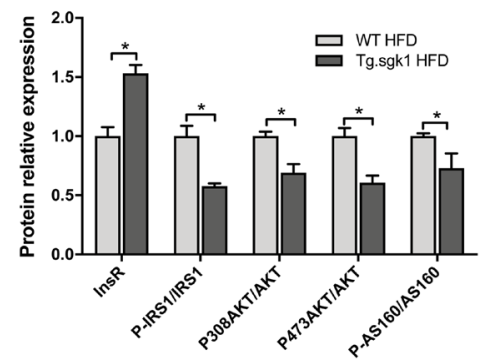

Figure 3

Tg.sgk1 mice show impaired glucose tolerance and insulin resistance. (A) Positive correlation between body weight and fasting glycemia in Tg.sgk1, but not in WT mice fed SCD. Spearman correlation: WT, $P=0.084 ;$ Tg.sgk1, $P=0.029$. Linear correlation slope in Tg.sgk1 = 3.9 $\pm 1.6(P=0.03)$; linear correlation slope in WT mice was not significantly different from zero $(P=0.128)$. (B) Glucose tolerance test (GTT) in WT and Tg.sgk1 kept in SCD or fed HFD for 5 weeks. Values are average glycemia \pm S.E.M. at the indicated time point after glucose load $(n=14 ;$ WT SCD; $n=13$, Tg.sgk1 SCD; $n=23$, WT HFD; $n=26$, Tg.sgk1 HFD). Two-way ANOVA followed by Tukey's multiple comparison test (Tg.sgk1 HFD vs Tg.sgk1 SCD, * $P<0.05 ;$ Tg.sgk1 HFD vs WT HFD, \#P<0.05; WT HFD vs WT SCD, \&P<0.05; Tg.sgk1 SCD vs WT SCD, $+P<0.05$; for simplicity the other three comparisons are not shown). (C) Individual points represent area under the curve (AUC) values obtained from each mice in the GTT curves shown in panel B. Average \pm S.E.M. AUC are also indicated. One-way ANOVA followed by Tukey's multiple comparison test: $* * p<0.01$, $* \star * p<0.001$. (D) Insulin Tolerance Test (ITT). Values represent average glycemia \pm S.E.M. ( $n=16$ ) at the indicated time point after insulin injection. Two-way ANOVA followed by Tukey's multiple comparison test (Tg.sgk1 HFD vs Tg.sgk1 SCD, * $P<0.05$; Tg.sgk1 HFD vs WT HFD, $\# P<0.05$; WT HFD vs WT SCD, \& $P<0.05$; for simplicity the other three comparisons are not shown; there were no significant differences between Tg.sgk1 and WT in SCD). (E) Individual points represent area under the curve (AUC) values obtained from each mice in the ITT curves shown in panel D. Average \pm S.E.M. AUC are also indicated. One-way ANOVA followed by Tukey's multiple comparison test ( $* P<0.05, * \star P<0.01$, $\star \star \star P<0.001)$. (F) Average insulinemia \pm S.E.M. at the indicated time points during GTT in mice fed with SCD or with HFD for 5 weeks $(n=7$, WT; $n=11$, Tg.sgk1). Two-way ANOVA followed by Tukey's multiple comparison test: Tg.sgk1 HFD vs Tg.sgk1 SCD, ** $P<0.01, * \star * P<0.001 ;$ Tg.sgk1 HFD vs WT SCD, ${ }^{++} P<0.01,{ }^{++} P<0.001$; Tg.sgk1 HFD vs WT HFD, \#\#P<0.01, \#\#P<0.001. (G) Individual points represent area under the curve (AUC) values obtained from each mice in the insulinemia curves shown in panel F. Average \pm S.E.M. AUC are also indicated. One-way ANOVA followed by Tukey's multiple comparison test ( $* P<0.05, * * P<0.01, * * * P<0.001)$. (H) Insulin signaling pathway analyzed by Western blot of epididymal adipose tissue from WT and Tg.sgk1 mice after 6 weeks on HFD $(n=5)$. Each lane corresponds to a sample from one animal. AS160, AKT substrate of $160 \mathrm{kDa}$; InsR, insulin receptor; IRS1, insulin receptor substrate 1. (I) Quantitative analysis of Western blots shown in panel H. Values represents average \pm S.E.M. (Student's $t$ test, * $P<0.05$ ).

\section{HFD-fed Tg.sgk1 mice rapidly develop hypertension}

To test whether SGK1 gain-of-function induces hypertension, we compared SBP measurements in WT and transgenic mice before and after HFD feeding. Animals kept in SCD did not show any differences on SBP between genotypes at 12 weeks of age (Fig. 5) or at later time points, even when challenged with high $\mathrm{NaCl}$ intake (data not shown). Remarkably, HFD produced a significant increase on SBP in transgenic mice after 4 weeks of HFD. Tg.sgk1 SBP continued increasing over time to reach an average of $173 \mathrm{mmHg}$ after 7 weeks on HFD and $184 \mathrm{mmHg}$ after 18 weeks, approximately $40-50 \mathrm{mmHg}$ higher than WT (Fig. 5). After 18 weeks of HFD WT animals also showed 

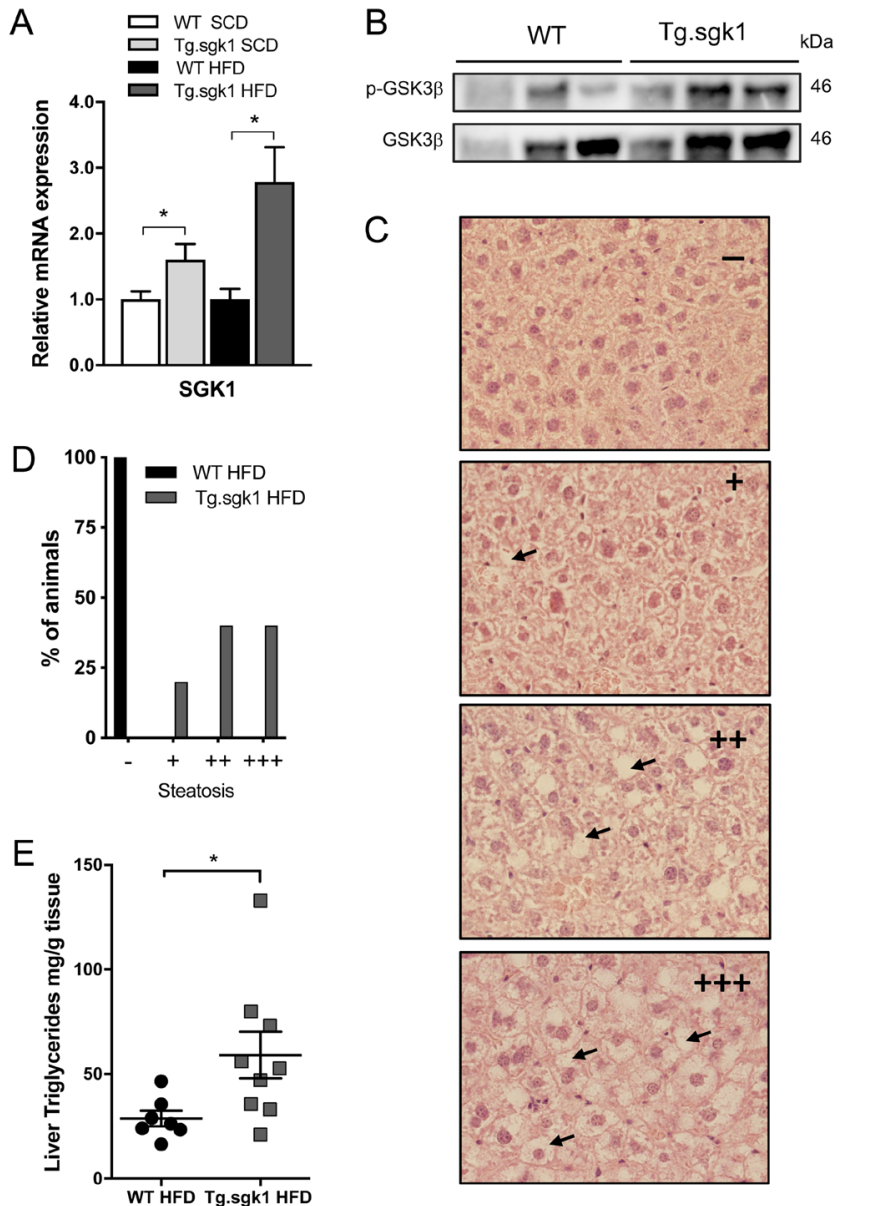

\section{Figure 4}

HFD produces liver steatosis in Tg.sgk1 mice. (A) Relative SGK1 mRNA expression in liver of WT and Tg.sgk1 mice under SCD or HFD. Values represent average \pm S.E.M. $(n=5-7)$. $* P<0.05$, one-way ANOVA followed by Sidak's multiple comparison test. (B) Representative immunoblot detecting phosphorylated GSK3 $\beta$ at residue $S 9$ and total GSK-3 $\beta$ in liver protein extracts from three different WT and Tg.sgk1 mice. (C) Representative images of hematoxylin-eosin-stained liver sections from WT or Tg.sgk1 mice fed a HFD for 6 weeks. (D) Semiquantitative analysis of lipid deposition in liver sections. Each bar represents the percentage of animals included in each score category $(-$, no lipid drops; +, ++, +++, increasing amounts of lipid drops). $n=6$. (E) Hepatic triglyceride content. Bars represent average \pm S.E.M. normalized to tissue weight ( $n=7$, WT; $n=9$, Tg.sgk1). * $P<0.05$, Student's $t$ test.

significantly elevated SBP when compared to animals on SCD (Fig. 5). Therefore, excess SGK1 sensitizes mice to rapidly developing hypertension when fed HFD.

\section{Discussion}

\section{SGK1 as a risk factor for obesity and MetS}

Available information strongly supports the idea that SGK1 constitutes a convergence point linking obesity, metabolic alterations and hypertension, all clustered in

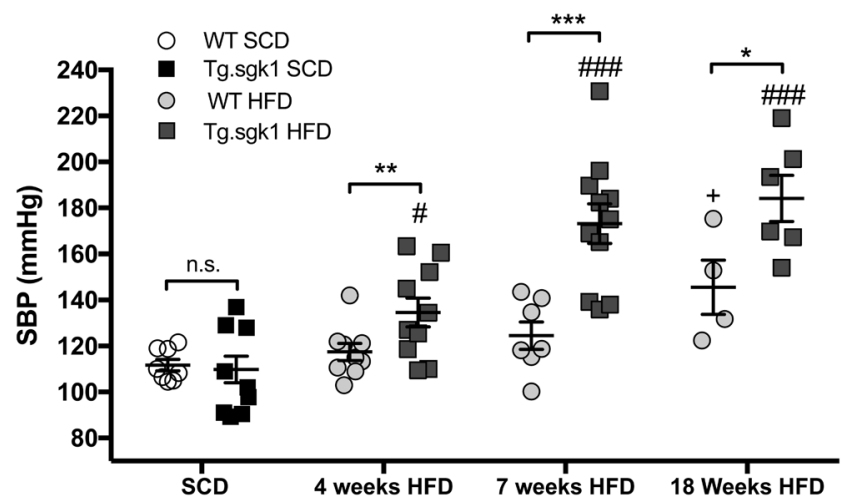

Figure 5

Excess SGK1 activity induces hypertension in HFD-fed mice. Individual points represent systolic blood pressure (SBP) obtained using the tail-cuff method on 12-week-old WT and Tg.sgk1 mice kept on SCD or after the indicated time on HFD ( $n=9$, SCD; $n=10, \mathrm{HFD}, 4$ weeks; $n=7$, WT HFD, 7 weeks; $n=11$, Tg.sgk1 HFD, 7 weeks; $n=4$, WT HFD, 18 weeks; $n=6$, Tg.sgk1 HFD, 18 weeks). Average values \pm S.E.M. are also represented. Two-way ANOVA followed by Bonferroni's multiple comparison test (WT vs Tg.sgk1: n.s., no significant difference; $* P<0.05 ; * \star P<0.01$; $\star \star * P<0.001 .{ }^{+} P<0.05$, WT SCD vs WT 18 weeks HFD. ${ }^{\#} P<0.05$, $\# \#$ \# $<0.001$, Tg.sgk1 SCD vs HFD).

the so-called MetS. From a mechanistic standpoint, these effects appeared to be multifactorial (see below). Therefore, our mouse model with systemic SGK1 expression under its own promoter but harboring a gain-of-function mutation appeared ideally suited to evaluate the role of this kinase in a complex and multi-organ condition such as the MetS. We found that excess SGK1 activity promotes adiposity together with hyperglycemia under a standard chow diet. The full deleterious effects of SGK1 were triggered by increased fat intake, leading to a very rapid and prominent development of other MetS components, most notably hypertension. This conclusion validates our hypothesis that a systemic increase in SGK1 activity constitutes a risk factor for metabolic disorders progression.

The adipose tissue was considered for a long time to be a passive fat storage compartment, but nowadays it is regarded as a versatile and central organ in the development of metabolic disorders. SGK1 is overexpressed in adipose tissue in obese mice and humans (Li et al. 2013) and it participates in HFD-induced adipogenesis (Ding et al. 2017). Our results using a gain-of-function SGK1 mutation support the involvement of SGK1 in adipocyte differentiation in vitro, as previously described in Sgk1knockout mouse model (Di Pietro et al. 2010). We found that activated SGK1 promotes lipid accumulation within the cytoplasm, probably due to increased glucose and FFA uptake. However, the role of SGK1 in energy metabolism is likely not restricted to adipocytes. SGK1 is also expressed in the liver, where it has been shown to regulate insulin 
sensitivity (Liu et al. 2014). Our data also suggest hepatic effects of SGK1, based on the hypertriglyceridemia detected under HFD and also the rapid development of NAFL. However, additional investigations are needed to decipher whether SGK1 has a direct effect on hepatocytes or an indirect effect related to the observed dyslipidemia leading to ectopic fat deposition. In skeletal muscle, SGK1 appears to be involved in increasing glucose transporter expression, glucose uptake and glycogen accumulation (Singh et al. 2013). Finally, a recent report showed that specific deletion of $S g k 1$ in POMC neurons increases adiposity induced by glucocorticoids (Deng et al. 2018).

The metabolic roles of SGK1 are added to its role in renal $\mathrm{Na}^{+}$handling and blood pressure control. Sgk1knockout animals do not shown altered SBP under normal conditions, but display impaired aldosterone-mediated increase in $\mathrm{Na}^{+}$reabsorption, leading to decreased blood pressure under low salt intake (Wulff et al. 2002, Faresse et al. 2012). SGK1 mediates the synergistic effect of insulin on aldosterone-induced $\mathrm{Na}^{+}$reabsorption through the epithelial $\mathrm{Na}^{+}$channel (Wang et al. 2001, Alvarez de la Rosa \& Canessa 2003). Recently, Norlander et al., showed that specific deletion of SGK1 in T cells blunts the increase in blood pressure in both the angiotensin II and DOCA/salt models of hypertension (Norlander et al. 2017), pointing to a multiplicity of mechanisms by which SGK1 may regulate blood pressure. Crucially, SGK1-knockout mice are protected against salt-dependent hypertension in the context of a high-fat (Huang et al. 2006b) or high-fructose diets (Huang et al. 2006a). In addition, SGK1 polymorphisms associate to increased blood pressure in humans (Busjahn et al. 2002), making carriers more susceptible to blood pressure increase associated to hyperinsulinemia (von Wowern et al. 2005). Our results represent the first analysis of increased SGK1 effects on blood pressure. In the absence of a challenge, SBP in transgenic animals is indistinguishable from WT. However, HFD produced a very rapid and large increase in blood pressure, in agreement with the notion that excess SGK1 activity may constitute a risk factor to develop hyperinsulinemia-related hypertension. Remarkably, in the absence of obesity and metabolic disturbances, a highsalt intake challenge did not raise SBP, suggesting that the coordinated activity of SGK1 in different tissues, and not just in the kidney, is responsible for this effect. The effects of increased SGK1 activity on blood pressure after a combined challenge of high-salt and high-fat intake remains to be determined.
The relevant upstream stimuli upregulating SGK1 expression in adipose tissue of mouse models of obesity as well as obese and diabetic patients remain elusive ( $\mathrm{Li}$ et al. 2013). Transcription of this kinase is regulated by several factors, including corticosteroids acting through the glucocorticoid and mineralocorticoid receptors (GR and MR, respectively) (Chen et al. 1999, NarayFejes-Toth et al. 1999, Webster et al. 1993). Systemic glucocorticoid excess such as during Cushing syndrome reproduce the main characteristics of MetS (Newell-Price et al. 2006). Several lines of evidence support a key role for both GR and MR in the pathogenesis of MetS by acting on several targets including the adipocyte, although there is conflicting evidence regarding the relative roles of each on adipocyte differentiation and function (Marzolla et al. 2012, Lee et al. 2014, Gomez-Sanchez 2015, Urbanet et al. 2015, Desarzens \& Faresse 2016). Remarkably, the use of a combined GR/MR antagonist significantly reduced the development of obesity in mice under HFD (Mammi et al. 2016). Our results suggest that at least some of the deleterious effects of GR/MR activation may be mediated through SGK1.

\section{SGK1 inhibition as a possible strategy to treat obesity-related hypertension}

Our study, together with previously available evidence, suggests that SGK1 is a potential target to treat obesityinduced hypertension. HFD-fed Sgk1-knockout mice are resistant to salt-sensitive hypertension, but not to hypertension induced by HFD alone (Huang et al. 2006b). Similarly, Sgk1-knockout mice are resistant to moderate increases in blood pressure induced by combined high-fructose and high-salt intake (Huang et al. 2006a), suggesting that the hypertensive effect of hyperinsulinemia may be associated to SGK1. In this context, preliminary studies using the SGK1 inhibitor EMD638683 lowered blood pressure in mice fed a high-fructose, high-salt diet (Ackermann et al. 2011). Furthermore, SGK1 inhibition showed beneficial effects in the development of obesity and hyperglycemia in $d b / d b$ mice (Li et al. 2016). However, Sgk1-knockout mice also show glucose intolerance and insulin resistance (Huang et al. 2006b), which could present a problem in longterm treatments inhibiting the kinase. In addition, the development of SGK1 inhibitors would have to overcome cross-reactivity with related kinases, including isoforms SGK2, SGK3 and AKT (Ackermann et al. 2011).
(C) 2020 Society for Endocrinology Published by Bioscientifica Ltd.
Printed in Great Britain 


\section{A new mouse model for MetS, related comorbidities and end organ damage}

One important observation made in this study is that HFD-fed Tg.sgk1 mice develop MetS features closer to the ones observed in humans, more rapidly and prominently than most available models. The availability of suitable rodent models to study the pathophysiological and molecular mechanisms of MetS progression is limited and most of them do not exhibit the entire clinical features observed in humans. The existing mouse models of MetS present several shortcomings, including the inconsistency of hypertension development in obese mice (Kennedy et al. 2010). Most models show coincident obesity and insulin resistance. However, the simultaneous presence of these two characteristics with dyslipidemia and hypertension is more difficult to achieve. In WT mice, 4 months of HFD raised the systolic blood pressure by $30-40 \mathrm{mmHg}$, confirming previous studies (Gupte et al. 2008, Marshall et al. 2013), although in other reports even this long treatment is not enough to raise blood pressure (Police et al. 2009). In Tg.sgk1 mice, a similar increase was reached after only 4 weeks of HFD and dramatically increased at longer time points. In addition to hypertension, all features of MetS appeared faster and more severe in our model. NAFL, a comorbidity commonly co-existing with MetS and hypertension (Cornier et al. 2008), is also accelerated in our model. Our results and other studies showed that 6 weeks of HFD has no effect on hepatic triglyceride levels in WT mice (Yamaguchi et al. 2007, Nam et al. 2015). In contrast, the same period of highfat feeding induces hepatic triglycerides accumulation in Tg.sgk1 comparable to levels found in C57BL/6 mice after 12 weeks in HFD (Nam et al. 2015).

\section{Limitations of this study and perspectives}

For practical reasons, our study included only male mice. Based on the known sexual dimorphism in susceptibility to obesity in mice (Hong et al. 2009), additional experiments are needed to test the effects of excess SGK1 activity on female mice. Also, it should be noted that a common weakness in studies using HFD vs standard chow is that diets are not isocaloric and matched for ingredients. Therefore, other ingredients varying between diets may also contribute to the phenotype described here. Most importantly, the effects of SGK1 described here are likely due to synergistic mechanisms affecting among others energy storage, insulin signaling and renal $\mathrm{Na}^{+}$ handling. Dissection of the relative importance of these mechanisms will need the development of tissue-specific conditional SGK1 gain-of-function models together with already available $S g k 1$-knockout lines.

From a translational perspective, our data further support the idea of SGK1 as a possible therapeutic target in MetS, particularly in situations where obesity co-exists with hypertension. Due to the fast and complete development of MetS with hypertension after a short HFD treatment, we propose that the SGK1 systemic gain-offunction model constitutes a useful experimental in vivo model for pre-clinical drug testing.

\section{Declaration of interest}

The authors declare that there is no conflict of interest that could be perceived as prejudicing the impartiality of the research reported.

\section{Funding}

This study was funded by Ministerio de Economía y Competitividad (BFU2016-78374-R) and Agencia Canaria de Investigación, Innovación y Sociedad de la Información (ProlD2017010135) to D A R. C S-R was partially supported by Campus de Excelencia Regional (Universidad de La Laguna, Spain). S V-G was supported by Programa Agustín de Betancourt (Cabildo de Tenerife, Spain).

\section{Acknowledgments}

The authors thank Dr Dawn E W Livingstone (University of Edinburgh) for advice on glucose homeostasis assessment, Dr Lucio Díaz-Flores and Dr Ricardo Gutiérrez (University of La Laguna) for advice on tissue histology, Dr Johannes Loffing (University of Zurich) for the kind gift of reagents and the Histology Facility at Centro Nacional de Biotecnología (Consejo Superior de Investigaciones Científicas, Spain) for preparation of tissue sections.

\section{References}

Ackermann TF, Boini KM, Beier N, Scholz W, Fuchss T \& Lang F 2011 EMD638683, a novel SGK inhibitor with antihypertensive potency. Cellular Physiology and Biochemistry 28 137-146. (https://doi. org/10.1159/000331722)

Alvarez de la Rosa D \& Canessa CM 2003 Role of SGK in hormonal regulation of epithelial sodium channel in A6 cells. American Journal of Physiology: Cell Physiology 284 C404-C414. (https://doi. org/10.1152/ajpcell.00398.2002)

Andres-Mateos E, Brinkmeier H, Burks TN, Mejias R, Files DC, Steinberger M, Soleimani A, Marx R, Simmers JL, Lin B, et al. 2013 Activation of serum/glucocorticoid-induced kinase 1 (SGK1) is important to maintain skeletal muscle homeostasis and prevent atrophy. EMBO Molecular Medicine 5 80-91. (https://doi.org/10.1002/ emmm.201201443)

Artunc F \& Lang F 2014 Mineralocorticoid and SGK1-sensitive inflammation and tissue fibrosis. Nephron. Physiology 128 35-39. (https://doi.org/10.1159/000368267)

Bowe JE, Franklin ZJ, Hauge-Evans AC, King AJ, Persaud SJ \& Jones PM 2014 Metabolic phenotyping guidelines: assessing glucose
(C) 2020 Society for Endocrinology Published by Bioscientifica Ltd.
Printed in Great Britain 
homeostasis in rodent models. Journal of Endocrinology 222 G13-G25. (https://doi.org/10.1530/JOE-14-0182)

Brunet A, Park J, Tran H, Hu LS, Hemmings BA \& Greenberg ME 2001 Protein kinase SGK mediates survival signals by phosphorylating the forkhead transcription factor FKHRL1 (FOXO3a). Molecular and Cellular Biology 21 952-965. (https://doi.org/10.1128/MCB.21.3.952965.2001)

Busjahn A, Aydin A, Uhlmann R, Krasko C, Bahring S, Szelestei T, Feng Y, Dahm S, Sharma AM, Luft FC, et al. 2002 Serum- and glucocorticoidregulated kinase (SGK1) gene and blood pressure. Hypertension $\mathbf{4 0}$ 256-260. (https://doi.org/10.1161/01.hyp.0000030153.19366.26)

Chen SY, Bhargava A, Mastroberardino L, Meijer OC, Wang J, Buse P, Firestone GL, Verrey F \& Pearce D 1999 Epithelial sodium channel regulated by aldosterone-induced protein sgk. PNAS 96 2514-2519. (https://doi.org/10.1073/pnas.96.5.2514)

Cornier MA, Dabelea D, Hernandez TL, Lindstrom RC, Steig AJ, Stob NR, Van Pelt RE, Wang H \& Eckel RH 2008 The metabolic syndrome. Endocrine Reviews 29 777-822. (https://doi.org/10.1210/er.2008-0024)

Debonneville C, Flores SY, Kamynina E, Plant PJ, Tauxe C, Thomas MA, Munster C, Chraibi A, Pratt JH, Horisberger JD, et al. 2001 Phosphorylation of Nedd4-2 by Sgk1 regulates epithelial $\mathrm{Na}(+)$ channel cell surface expression. EMBO Journal 20 7052-7059. (https:// doi.org/10.1093/emboj/20.24.7052)

Deng Y, Xiao Y, Yuan F, Liu Y, Jiang X, Deng J, Fejes-Toth G, NarayFejes-Toth A, Chen S, Chen Y, et al. 2018 SGK1/FOXO3 signaling in hypothalamic POMC neurons mediates glucocorticoid-increased adiposity. Diabetes 67 569-580. (https://doi.org/10.2337/db17-1069)

Desarzens S \& Faresse N 2016 Adipocyte glucocorticoid receptor has a minor contribution in adipose tissue growth. Journal of Endocrinology 230 1-11. (https://doi.org/10.1530/JOE-16-0121)

Di Chiara M, Glaudemans B, Loffing-Cueni D, Odermatt A, Al-Hasani H, Devuyst O, Faresse N \& Loffing J 2015 Rab-GAP TBC1D4 (AS160) is dispensable for the renal control of sodium and water homeostasis but regulates GLUT4 in mouse kidney. American Journal of Physiology: Renal Physiology 309 F779-F790. (https://doi.org/10.1152/ ajprenal.00139.2015)

Di Pietro N, Panel V, Hayes S, Bagattin A, Meruvu S, Pandolfi A, Hugendubler L, Fejes-Toth G, Fejes-Tóth G, Naray-Fejes-Tóth A \& Mueller E 2010 Serum- and glucocorticoid-inducible kinase 1 (SGK1) regulates adipocyte differentiation via forkhead box O1. Molecular Endocrinology 24 370-380. (https://doi.org/10.1210/me.2009-0265)

Dieter M, Palmada M, Rajamanickam J, Aydin A, Busjahn A, Boehmer C, Luft FC \& Lang F 2004 Regulation of glucose transporter SGLT1 by ubiquitin ligase Nedd4-2 and kinases SGK1, SGK3, and PKB. Obesity Research 12 862-870. (https://doi.org/10.1038/oby.2004.104)

Ding L, Zhang L, Biswas S, Schugar RC, Brown JM, Byzova T \& Podrez E 2017 Akt3 inhibits adipogenesis and protects from diet-induced obesity via WNK1/SGK1 signaling. JCI Insight 2 95687. (https://doi. org/10.1172/jci.insight.95687)

Draznin B 2006 Molecular mechanisms of insulin resistance: serine phosphorylation of insulin receptor substrate- 1 and increased expression of p85alpha: the two sides of a coin. Diabetes 55 23922397. (https://doi.org/10.2337/db06-0391)

Faresse N, Lagnaz D, Debonneville A, Ismailji A, Maillard M, Fejes-Toth G, Náray-Fejes-Tóth A \& Staub O 2012 Inducible kidney-specific Sgk 1 knockout mice show a salt-losing phenotype. American Journal of Physiology: Renal Physiology 302 F977-F985. (https://doi.org/10.1152/ ajprenal.00535.2011)

Garcia-Martinez JM \& Alessi DR 2008 mTOR complex 2 (mTORC2) controls hydrophobic motif phosphorylation and activation of serum- and glucocorticoid-induced protein kinase 1 (SGK1). Biochemical Journal 416 375-385. (https://doi.org/10.1042/ BJ20081668)

Gomez-Sanchez CE 2015 What is the role of the adipocyte mineralocorticoid receptor in the metabolic syndrome? Hypertension 66 17-19. (https://doi.org/10.1161/HYPERTENSIONAHA.115.05148)
Gupte M, Boustany-Kari CM, Bharadwaj K, Police S, Thatcher S, Gong MC, English VL \& Cassis LA 2008 ACE2 is expressed in mouse adipocytes and regulated by a high-fat diet. American Journal of Physiology: Regulatory, Integrative and Comparative Physiology 295 R781-R788. (https://doi.org/10.1152/ajpregu.00183.2008)

Hong J, Stubbins RE, Smith RR, Harvey AE \& Nunez NP 2009 Differential susceptibility to obesity between male, female and ovariectomized female mice. Nutrition Journal 8 11. (https://doi.org/10.1186/14752891-8-11)

Huang DY, Boini KM, Friedrich B, Metzger M, Just L, Osswald H, Wulff P, Kuhl D, Vallon V \& Lang F 2006a Blunted hypertensive effect of combined fructose and high-salt diet in gene-targeted mice lacking functional serum- and glucocorticoid-inducible kinase SGK1. American Journal of Physiology: Regulatory, Integrative and Comparative Physiology 290 R935-R944. (https://doi.org/10.1152/ ajpregu.00382.2005)

Huang DY, Boini KM, Osswald H, Friedrich B, Artunc F, Ullrich S, Rajamanickam J, Palmada M, Wulff P, Kuhl D, et al. 2006b Resistance of mice lacking the serum- and glucocorticoid-inducible kinase SGK1 against salt-sensitive hypertension induced by a high-fat diet. American Journal of Physiology: Renal Physiology 291 F1264-F1273. (https://doi.org/10.1152/ajprenal.00299.2005)

Kennedy AJ, Ellacott KL, King VL \& Hasty AH 2010 Mouse models of the metabolic syndrome. Disease Models and Mechanisms 3 156-166. (https://doi.org/10.1242/dmm.003467)

Kim JI, Huh JY, Sohn JH, Choe SS, Lee YS, Lim CY, Jo A, Park SB, Han W \& Kim JB 2015 Lipid-overloaded enlarged adipocytes provoke insulin resistance independent of inflammation. Molecular and Cellular Biology 35 1686-1699. (https://doi.org/10.1128/MCB.01321-14)

Kleiner DE, Brunt EM, Van Natta M, Behling C, Contos MJ, Cummings OW, Ferrell LD, Liu YC, Torbenson MS, Unalp-Arida A, et al. 2005 Design and validation of a histological scoring system for nonalcoholic fatty liver disease. Hepatology 41 1313-1321. (https:// doi.org/10.1002/hep.20701)

Kobayashi T \& Cohen P 1999 Activation of serum- and glucocorticoid-regulated protein kinase by agonists that activate phosphatidylinositide 3-kinase is mediated by 3-phosphoinositidedependent protein kinase-1 (PDK1) and PDK2. Biochemical Journal 339 319-328. (https://doi.org/10.1042/bj3390319)

Kolterman OG, Insel J, Saekow M \& Olefsky JM 1980 Mechanisms of insulin resistance in human obesity: evidence for receptor and postreceptor defects. Journal of Clinical Investigation 65 1272-1284. (https://doi.org/10.1172/JCI109790)

Lang F, Bohmer C, Palmada M, Seebohm G, Strutz-Seebohm N \& Vallon V 2006 (Patho)physiological significance of the serum- and glucocorticoid-inducible kinase isoforms. Physiological Reviews $\mathbf{8 6}$ 1151-1178. (https://doi.org/10.1152/physrev.00050.2005)

Lee MJ \& Fried SK 2014 Reply to Armani et al. Can cortisol stimulate adipogenesis without the glucocorticoid receptor? International Journal of Obesity 38 1578-1579. (https://doi.org/10.1038/ijo.2014.71)

Li P, Pan F, Hao Y, Feng W, Song H \& Zhu D 2013 SGK1 is regulated by metabolic-related factors in 3T3-L1 adipocytes and overexpressed in the adipose tissue of subjects with obesity and diabetes. Diabetes Research and Clinical Practice 102 35-42. (https://doi.org/10.1016/j. diabres.2013.08.009)

Li P, Hao Y, Pan FH, Zhang M, Ma JQ \& Zhu DL 2016 SGK1 inhibitor reverses hyperglycemia partly through decreasing glucose absorption. Journal of Molecular Endocrinology 56 301-309. (https://doi. org/10.1530/JME-15-0285)

Liu H, Yu J, Xia T, Xiao Y, Zhang Q, Liu B, Guo Y, Deng J, Deng Y, Chen S, et al. 2014 Hepatic serum- and glucocorticoid-regulated protein kinase 1 (SGK1) regulates insulin sensitivity in mice via extracellular-signalregulated kinase 1/2 (ERK1/2). Biochemical Journal 464 281-289. (https://doi.org/10.1042/BJ20141005)

Mammi C, Marzolla V, Armani A, Feraco A, Antelmi A, Maslak E, Chlopicki S, Cinti F, Hunt H, Fabbri A, et al. 2016 A novel combined https://joe.bioscientifica.com

https://doi.org/10.1530/JOE-19-0275 (c) 2020 Society for Endocrinology Published by Bioscientifica Ltd. Printed in Great Britain 
glucocorticoid-mineralocorticoid receptor selective modulator markedly prevents weight gain and fat mass expansion in mice fed a high-fat diet. International Journal of Obesity 40 964-972. (https://doi. org/10.1038/ijo.2016.13)

Marshall NJ, Liang L, Bodkin J, Dessapt-Baradez C, Nandi M, CollotTeixeira S, Smillie SJ, Lalgi K, Fernandes ES, Gnudi L, et al. 2013 A role for TRPV1 in influencing the onset of cardiovascular disease in obesity. Hypertension 61 246-252. (https://doi.org/10.1161/ HYPERTENSIONAHA.112.201434)

Marzolla V, Armani A, Zennaro MC, Cinti F, Mammi C, Fabbri A, Rosano GM \& Caprio M 2012 The role of the mineralocorticoid receptor in adipocyte biology and fat metabolism. Molecular and Cellular Endocrinology 350 281-288. (https://doi.org/10.1016/j. mce.2011.09.011)

Miranda P, Cadaveira-Mosquera A, Gonzalez-Montelongo R, Villarroel A, Gonzalez-Hernandez T, Lamas JA, Alvarez de la Rosa D \& Giraldez T 2013 The neuronal serum- and glucocorticoid-regulated kinase 1.1 reduces neuronal excitability and protects against seizures through upregulation of the M-current. Journal of Neuroscience 33 2684-2696. (https://doi.org/10.1523/JNEUROSCI.3442-12.2013)

Muniyappa R, Lee S, Chen H \& Quon MJ 2008 Current approaches for assessing insulin sensitivity and resistance in vivo: advantages, limitations, and appropriate usage. American Journal of Physiology: Endocrinology and Metabolism 294 E15-E26. (https://doi.org/10.1152/ ajpendo.00645.2007)

Nam M, Choi MS, Jung S, Jung Y, Choi JY, Ryu DH \& Hwang GS 2015 Lipidomic profiling of liver tissue from obesity-prone and obesityresistant mice fed a high fat diet. Scientific Reports 5 16984. (https:// doi.org/10.1038/srep16984)

Náray-Fejes-Tóth A, Canessa C, Cleaveland ES, Aldrich G \& FejesTóth G 1999 sgk is an aldosterone-induced kinase in the renal collecting duct. Effects on epithelial na+ channels. Journal of Biological Chemistry 274 16973-16978. (https://doi.org/10.1074/ jbc.274.24.16973)

Newell-Price J, Bertagna X, Grossman AB \& Nieman LK 2006 Cushing's syndrome. Lancet 367 1605-1617. (https://doi.org/10.1016/S01406736(06)68699-6)

Norlander AE, Saleh MA, Pandey AK, Itani HA, Wu J, Xiao L, Kang J, Dale BL, Goleva SB, Laroumanie F, et al. 2017 A salt-sensing kinase in T lymphocytes, SGK1, drives hypertension and hypertensive end-organ damage. JCI Insight 2 92801. (https://doi.org/10.1172/jci. insight.92801)

Pacini G, Omar B \& Ahren B 2013 Methods and models for metabolic assessment in mice. Journal of Diabetes Research 2013 986906. (https:// doi.org/10.1155/2013/986906)

Pearce D 2003 SGK1 regulation of epithelial sodium transport. Cellular Physiology and Biochemistry 13 13-20. (https://doi. org/10.1159/000070245)

Police SB, Thatcher SE, Charnigo R, Daugherty A \& Cassis LA 2009 Obesity promotes inflammation in periaortic adipose tissue and angiotensin II-induced abdominal aortic aneurysm formation. Arteriosclerosis, Thrombosis, and Vascular Biology 29 1458-1464. (https://doi.org/10.1161/ATVBAHA.109.192658)
Schwab M, Lupescu A, Mota M, Mota E, Frey A, Simon P, Mertens PR, Floege J, Luft F, Asante-Poku S, et al. 2008 Association of SGK1 gene polymorphisms with type 2 diabetes. Cellular Physiology and Biochemistry 21 151-160. (https://doi.org/10.1159/000113757)

Shoelson SE, Lee J \& Goldfine AB 2006 Inflammation and insulin resistance. Journal of Clinical Investigation 116 1793-1801. (https://doi. org/10.1172/JCI29069)

Singh PK, Singh S \& Ganesh S 2013 Activation of serum/glucocorticoidinduced kinase 1 (SGK1) underlies increased glycogen levels, mTOR activation, and autophagy defects in Lafora disease. Molecular Biology of the Cell 24 3776-3786. (https://doi.org/10.1091/mbc.E13-05-0261)

Sun K, Kusminski CM \& Scherer PE 2011 Adipose tissue remodeling and obesity. Journal of Clinical Investigation 121 2094-2101. (https://doi. org/10.1172/JCI45887)

Urbanet R, Nguyen Dinh Cat A, Feraco A, Venteclef N, El Mogrhabi S, Sierra-Ramos C, Alvarez de la Rosa D, Adler GK, Quilliot D, Rossignol P, et al. 2015 Adipocyte mineralocorticoid receptor activation leads to metabolic syndrome and induction of prostaglandin D2 synthase. Hypertension 66 149-157. (https://doi. org/10.1161/HYPERTENSIONAHA.114.04981)

Verrey F, Loffing J, Zecevic M, Heitzmann D \& Staub O 2003 SGK1: aldosterone-induced relay of $\mathrm{Na}+$ transport regulation in distal kidney nephron cells. Cellular Physiology and Biochemistry 13 21-28. (https:// doi.org/10.1159/000070246)

von Wowern F, Berglund G, Carlson J, Mansson H, Hedblad B \& Melander O 2005 Genetic variance of SGK-1 is associated with blood pressure, blood pressure change over time and strength of the insulin-diastolic blood pressure relationship. Kidney International $\mathbf{6 8}$ 2164-2172. (https://doi.org/10.1111/j.1523-1755.2005.00672.x)

Wang J, Barbry P, Maiyar AC, Rozansky DJ, Bhargava A, Leong M, Firestone GL \& Pearce D 2001 SGK integrates insulin and mineralocorticoid regulation of epithelial sodium transport. American Journal of Physiology: Renal Physiology 280 F303-F313. (https://doi. org/10.1152/ajprenal.2001.280.2.F303)

Webster MK, Goya L, Ge Y, Maiyar AC \& Firestone GL 1993 Characterization of sgk, a novel member of the serine/threonine protein kinase gene family which is transcriptionally induced by glucocorticoids and serum. Molecular and Cellular Biology 132031 2040. (https://doi.org/10.1128/mcb.13.4.2031)

Wulff P, Vallon V, Huang DY, Volkl H, Yu F, Richter K, Jansen M, Schlunz M, Klingel K, Loffing J, et al. 2002 Impaired renal $\mathrm{Na}(+)$ retention in the sgk1-knockout mouse. Journal of Clinical Investigation 110 1263-1268. (https://doi.org/10.1172/JCI15696)

Wyatt AW, Hussain A, Amann K, Klingel K, Kandolf R, Artunc F, Grahammer F, Huang DY, Vallon V, Kuhl D, et al. 2006 DOCAinduced phosphorylation of glycogen synthase kinase 3beta. Cellular Physiology and Biochemistry 17 137-144. (https://doi. org/10.1159/000092075)

Yamaguchi K, Yang L, McCall S, Huang J, Yu XX, Pandey SK, Bhanot S, Monia BP, Li YX \& Diehl AM 2007 Inhibiting triglyceride synthesis improves hepatic steatosis but exacerbates liver damage and fibrosis in obese mice with nonalcoholic steatohepatitis. Hepatology $\mathbf{4 5}$ 1366-1374. (https://doi.org/10.1002/hep.21655)

Received in final form 12 September 2019

Accepted 10 October 2019

Accepted Manuscript published online 10 October 2019 https://joe.bioscientifica.com https://doi.org/10.1530/JOE-19-0275 (c) 2020 Society for Endocrinology Published by Bioscientifica Ltd. Printed in Great Britain 